\title{
A multiannual survey of cadmium content in pig tissues collected in the Czech Republic during the years 2015-2019
}

\author{
Martin Svoboda $^{1}$, Jiří Drápal ${ }^{2}$, Danka Haruštiaková ${ }^{3,4}, Z_{\text {deňka Svobodová }}^{5}$ \\ ${ }^{1}$ University of Veterinary and Pharmaceutical Sciences Brno, Faculty of Veterinary Medicine, \\ Ruminant and Swine Clinic, Brno, Czech Republic \\ ${ }^{2}$ Central Veterinary Administration of the State Veterinary Administration, Prague, Czech Republic \\ ${ }^{3}$ Masaryk University, Faculty of Medicine, Institute of Biostatistics and Analyses, Brno, Czech Republic \\ ${ }^{4}$ Masaryk University, Faculty of Science, Research Centre for Toxic Compounds in the Environment, \\ Brno, Czech Republic \\ ${ }^{5}$ University of Veterinary and Pharmaceutical Sciences Brno, Faculty of Veterinary Hygiene and Ecology, \\ Department of Animal Protection and Welfare and Veterinary Public Health, Brno, Czech Republic
}

Received July 27, 2020

Accepted December 21, 2020

\begin{abstract}
The assessment of cadmium content in the muscle, liver and kidneys of fattening pigs and sows was conducted in the Czech Republic during the period of 2015-2019. The samples were collected from a total of 32 sows and 210 fattening pigs. The mean cadmium content in the livers and kidneys of all sows was $0.102 \pm 0.010$ and $0.361 \pm 0.032 \mathrm{mg} \cdot \mathrm{kg}^{-1}$, respectively. The mean cadmium content in the livers and kidneys of all fattening pigs was $0.028 \pm 0.001$ and $0.141 \pm 0.005 \mathrm{mg} \cdot \mathrm{kg}^{-1}$, respectively. The maximum residual limit for human consumption was not exceeded in any sample. The cadmium content in the liver did not differ significantly between sows and fattening pigs in any particular year. In contrast, the cadmium content in kidneys differed significantly between sows and fattening pigs, being higher in sows $(P<0.05)$. No significant decreasing trend was observed for the cadmium content in tissues during the whole time period. It can be concluded that there is a need for further monitoring of the cadmium content in pig tissues in the Czech Republic.
\end{abstract}

Heavy metals, kidney, sow, fattening pig

Heavy metals are present in soil, water and air and their harmful effects on human and animal health are well known ( $\mathrm{Li}$ et al. 2019). Cadmium is one of the most important contaminants. Prolonged exposure to low doses of cadmium can have an effect on human health, and great effort is exerted to minimize the exposure of the general public to the metal (Grawé et al. 1997). The toxic effect of cadmium lies in its negative impact on the enzymatic systems of cells. Cadmium has a very strong affinity for biological structures containing SH groups, such as proteins, enzymes, and nucleic acids (Stohs 1995). Another area of growing concern about cadmium is its multi-tissue carcinogenicity (Waalkes 2000). Compared to other potentially harmful environmental substances, cadmium is more easily transported from soil through the root system to the edible part of agricultural crops (Jalil et al. 1994; McLaughlin et al. 1996). Cadmium is a toxic metal that easily accumulates in the body. It has been shown to accumulate in almost all animal tissues, particularly in the liver and kidneys (Satarug et al. 2003). The source of cadmium in the viscera of pigs is most likely the feed with a high concentration of naturally occurring cadmium (Grawé et al. 1997). The determination of cadmium in pig tissues is carried out in the framework of monitoring programs which take place in many countries in order to avoid the distribution of food that could pose a risk to human health. The aim of the present paper was to analyze and present the results of a multiannual survey of cadmium content in pig tissues collected in the Czech Republic during the years 2015-2019.

Address for correspondence:

Doc. MVDr. Martin Svoboda, Ph.D.

Ruminant and Swine Clinic

Faculty of Veterinary Medicine

University of Veterinary and Pharmaceutical Sciences Brno

Palackého tř. 1946/1, 61242 Brno, Czech Republic 


\section{Materials and Methods}

The samples of pig tissues were collected by the Czech State Veterinary Administration within the national plan for the monitoring of residues and contaminants in accordance with the Council Directive 96/23/EC (1996) in the years 2015-2019. The minimum number of animals from which the tissue samples were taken was calculated according to the methodology of the aforementioned directive. Veterinary inspectors randomly selected slaughtered fattening pigs and sows for tissue sampling at various slaughterhouses of the Czech Republic. Pigs for fattening were slaughtered at the usual slaughter weight of about $90-110 \mathrm{~kg}$ at the age of 6 to 7 months. The goal was to cover as large an area as possible. Samples included muscle (lean meat), any part of the liver (sample of at least $0.5 \mathrm{~kg}$ ) and the whole kidney. The determination was carried out in the laboratories of the State Veterinary Institutes in the Czech Republic. All laboratories were accredited according to EN ISO/IEC 17025 and regularly participate in inter-laboratory comparison tests. Methods used were validated and the quality of routine analyses was controlled by testing of reference, duplicate and blank samples.

Homogenized samples of biological material were mineralized in a microwave device after the addition of concentrated nitric acid and hydrogen peroxide. The decomposition was conducted using a program operated by a control unit. After the decomposition was complete, the measurement of the cadmium content was carried out using electrothermal atomic absorption spectrometry with Zeeman correction (ET-AAS, or GF-AAS), or in some cases using inductively coupled plasma mass spectrometry (ICP-MS). In the case of the ET-AAS method, the mineralized sample was atomized by heating according to the temperature program in an electrically heated atomizer (graphite cuvette). The absorbance of cadmium was measured at a wavelength of $228.8 \mathrm{~nm}$, which is directly proportional to the concentration of cadmium in the sample. In the case of the ICP-MS method, the mineralized sample was nebulized with the help of a conical nebulizer and cooling chamber and introduced into plasma, where the elements are freed from their chemical bonds due to the temperature of argon plasma (approx. $10000 \mathrm{~K}$ ), ionized and directed into the quadrupole. The ions are selected according to their $\mathrm{M} / \mathrm{Z}$ (mass/charge) and the resultant ion beam is fed into an electron multiplier, which detects the impact of the individual ions. The number of ${ }^{111}$ cadmium ions which enter the detector is directly proportional to the concentration of cadmium in the sample. The required level of quantification (LOQ) in the tissues for the methods used was $0.01 \mathrm{mg} \cdot \mathrm{kg}^{-1}$ for the liver and kidneys, and $0.005 \mathrm{mg} \cdot \mathrm{kg}^{-1}$ for the muscle.

\section{Data manipulation and statistical analysis}

The number of analysed samples varied from 4 to 46 in sow/fattening pig in different years. The cadmium content in the muscle tissue was found to be below the LOQ in almost all samples, making the statistical comparison impossible. The differences in the cadmium content between years, sows/pigs and liver/kidney were analysed using the factorial ANOVA followed by Fisher post hoc test for unequal N. The evaluation of time trends was performed using the Pearson correlation coefficient. $P<0.05$ was considered significant in all tests. The data manipulation and statistical analysis were performed using Statistica, version 13 (TIBCO Software Inc.).

\section{Results}

The cadmium content in muscle tissue was below LOQ $\left(<0.005 \mathrm{mg} \cdot \mathrm{kg}^{-1}\right.$ of wet weight $)$ in 29 of 31 samples from sows, and in 208 of 210 samples from fattening pigs. The remaining values were 0.006 and $0.007 \mathrm{mg} \cdot \mathrm{kg}^{-1}$ in sows and 0.005 and $0.008 \mathrm{mg} \cdot \mathrm{kg}^{-1}$ in fattening pigs.

The cadmium content in the liver and kidneys of sows and fattening pigs during 2015-2019 is presented in Table 1 and Fig. 1. The cadmium content varied between 0.008 and $0.201 \mathrm{mg} \cdot \mathrm{kg}^{-1}$ of wet weight in the liver, and between 0.026 and $0.764 \mathrm{mg} \cdot \mathrm{kg}^{-1}$ of wet weight in the kidneys. The maximum residual limit (MRL) for human consumption was not exceeded in any sample (MRL for cadmium in liver: $0.50 \mathrm{mg} \cdot \mathrm{kg}^{-1}$; MRL for cadmium in kidney: $1.0 \mathrm{mg} \cdot \mathrm{kg}^{-1}$; European Commission 2006) (Table 1).

The cadmium content was significantly affected by the age category of pigs (sows/fattening pigs) (factorial ANOVA, the effect of the age category: $\mathrm{F}(1,471)=214.260, P<0.001$ ) and tissue (factorial ANOVA, the effect of tissue: $\mathrm{F}(1,471)=399.004, P<0.001$ ). No effect of year was found (factorial ANOVA, the effect of year: $\mathrm{F}(4,471)=0.876, P=0.478$ ).

The cadmium content in the liver did not differ significantly between sows and fattening pigs in any particular year. In contrast, the cadmium content in the kidneys differed significantly between sows and fattening pigs in all but one year (2018), being higher in sows. The differences between the liver and kidneys were significant in sows as well as in fattening pigs in all years. In all comparisons, the cadmium content in the kidneys was higher than in the liver (Table 1, Fig. 1). 


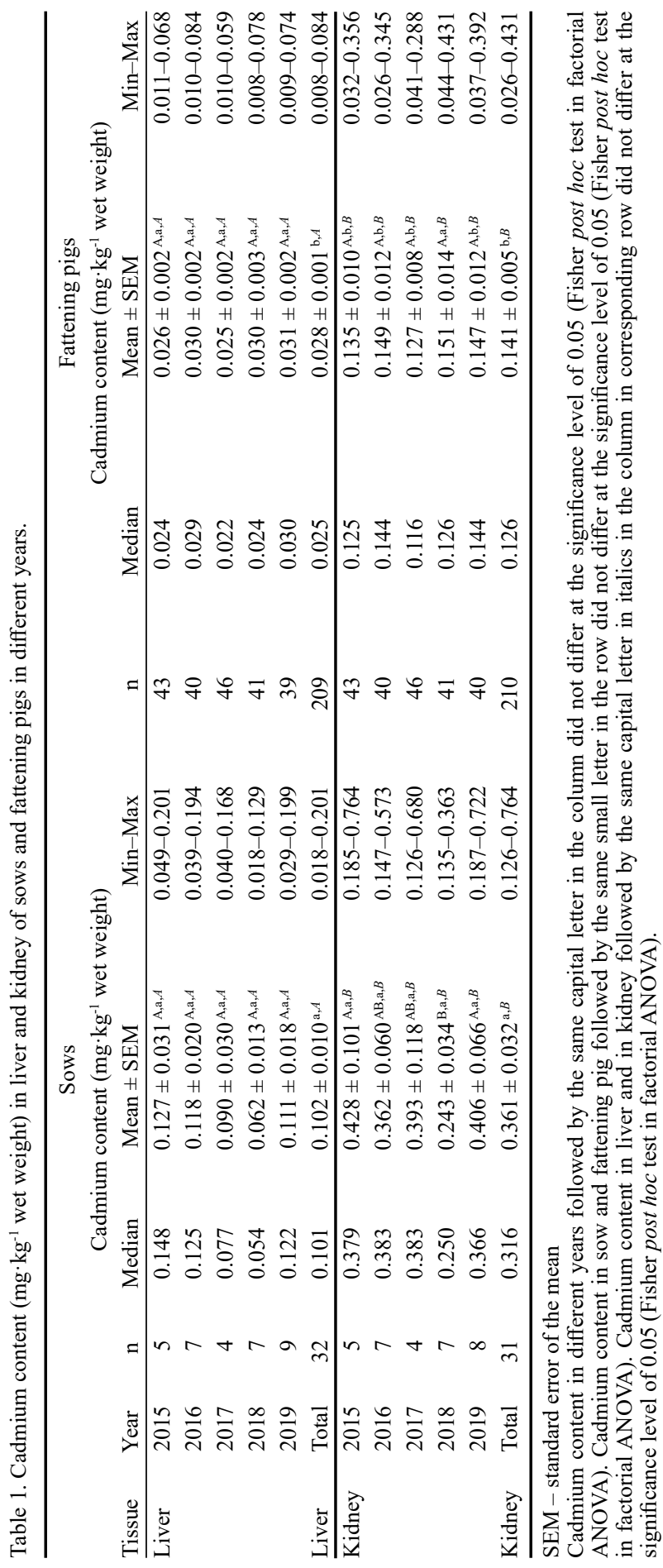

Although the general effect of year was not significant, a number of between-year differences were found in the kidneys of sows, being the lowest in 2018, and the highest in 2015 and 2019. However, no significant decrease in the cadmium content in tissues was observed during the whole time period (the correlation coefficient between the mean cadmium content and year varied from -0.539 to 0.546 , $P>0.05$ in all cases).

\section{Discussion}

The anthropogenic use of cadmium during the last century has increased the cadmium emissions to air, water, and soil. This led to an increase in the cadmium concentrations in arable land and crops during the $20^{\text {th }}$ century (Lindén et al. 2003). Cadmium contamination of soil and water causes its inclusion in the food chain, which can result in a wide range of adverse effects on animals and humans, as it is a cumulative contaminant (Tu et al. 2007). Cadmium is easily taken up from soil by plants (Lindén et al. 2003). The main source of cadmium in the tissues of pigs is most likely their feed. In particular, many feed components such as phosphorus sources and trace mineral premixes may contain cadmium (Handson 1991).

The conversion of cadmium into tissues is much slower than that of lead or mercury (Ammerman et al. 1977). Cadmium is therefore a toxic metal that easily accumulates 


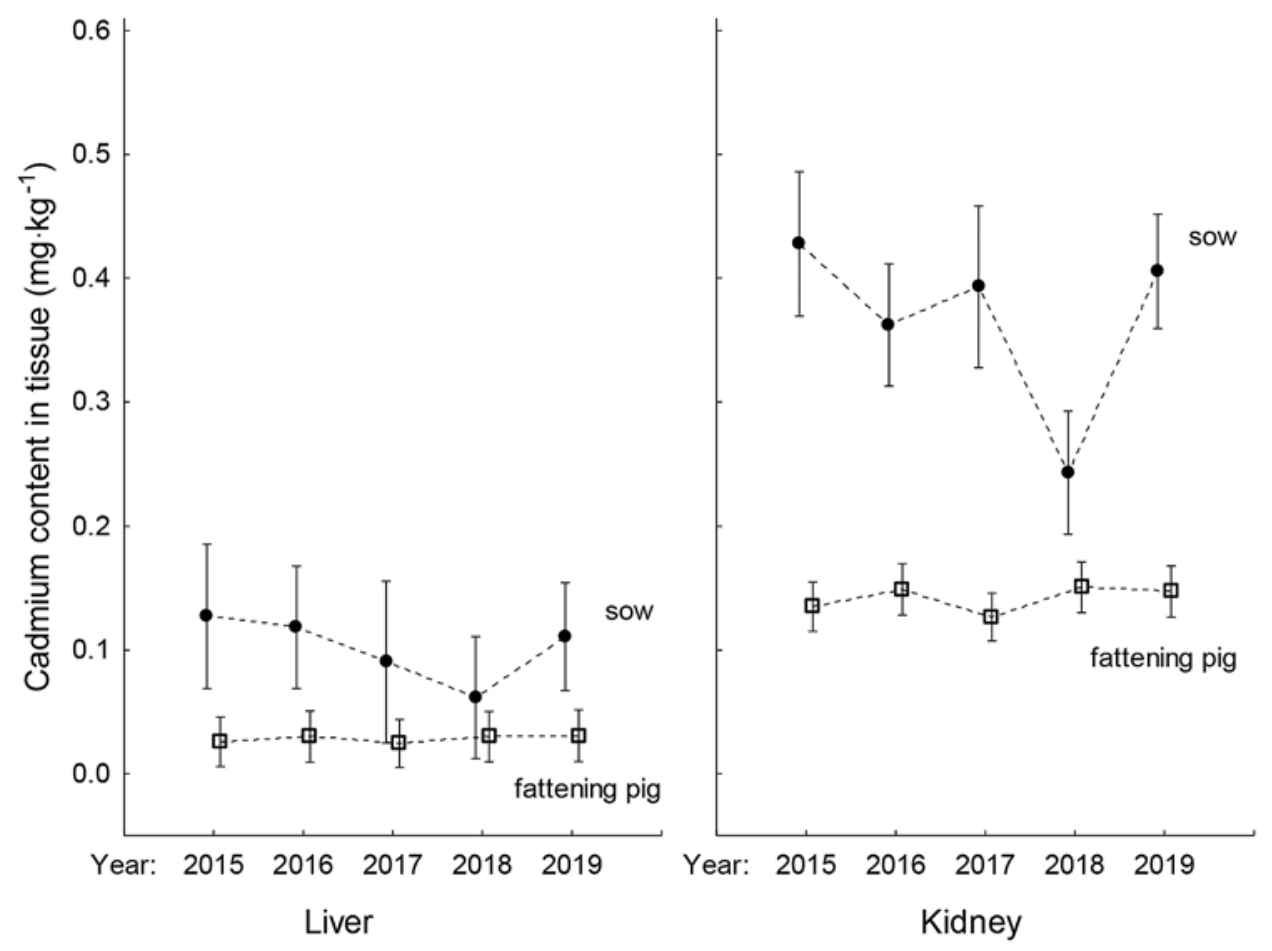

Fig. 1. Cadmium content in livers and kidneys of sows and fattening pigs during 2015-2019 (mean and 0.95 confidence interval)

in the body. With regard to the consumption of pig-derived food, only the kidneys and liver of pigs can accumulate a sufficient amount of cadmium to cause concern (Satarug et al. 2003).

Pigs are usually fed by locally produced cereals. Cereals are the main source of cadmium intake in humans. Therefore, the concentration of cadmium in the kidneys of pigs may be an indicator of the presence of cadmium in the agricultural environment. This can reflect both the transition of cadmium from soil to crops and its absorption from feed, and its retention in the animal organism (Grawé et al. 1997).

In the available literature there are many differences in the cadmium tissue content between authors. These data are based mostly on analyses conducted in fattening pigs. For instance, in Spain, López-Alonso et al. (2007) found the following mean values: liver $0.073 \pm 0.019 \mathrm{mg} \cdot \mathrm{kg}^{-1}$, kidney $0.308 \pm 0.103 \mathrm{mg} \cdot \mathrm{kg}^{-1}$, muscle $0.009 \pm 0.007 \mathrm{mg} \cdot \mathrm{kg}^{-1}$. Falandysz (1993) reported these mean values in Poland: liver $0.041 \mathrm{mg} \cdot \mathrm{kg}^{-1}$, kidney $0.24 \mathrm{mg} \cdot \mathrm{kg}^{-1}$, muscle $0.005 \mathrm{mg} \cdot \mathrm{kg}^{-1}$. In Hungary, Györi et al. (2005) present the following mean values: liver $0.012 \mathrm{mg} \cdot \mathrm{kg}^{-1}$, kidney $0.066 \mathrm{mg} \cdot \mathrm{kg}^{-1}$, muscle $0.011 \mathrm{mg} \cdot \mathrm{kg}^{-1}$. In Serbia, Nikolic et al. (2017) measured these mean values muscle n.d., liver $0.051 \pm 002 \mathrm{mg} \cdot \mathrm{kg}^{-1}$, kidney $0.220 \pm 0.008 \mathrm{mg} \cdot \mathrm{kg}^{-1}$.

The differences in the cadmium content in pig tissues found in this study and the values reported by other authors can be caused by the following factors. The main source of 
cadmium in the tissues of pigs is most likely the feed. Cadmium is easily taken up from soil by plants (Lindén et al. 2003). The cadmium contamination of soil is a ubiquitous environmental problem that has resulted from uncontrolled industrialization (Khan et al. 2017). However, the concentration of cadmium in the soil is only one of the factors influencing the amount of cadmium in the crop. Other factors, such as soil organic matter, soil $\mathrm{pH}$, crop rotation, cation exchange capacity, micro and macro nutrients, crop species and cultivar also affect the cadmium capture in plants (Erikson et al. 1996; Hamon et al. 1997; Hamon et al. 1998). According to Oborn et al. (1995), excessive liming increased the cadmium capture in crops, probably due to the ion exchange process. Changes in the agricultural methods used, resulting in a lower organic matter content in the soil, can also lead to a higher cadmium uptake by plants (Oborn et al. 1995). Also other feed components, such as phosphorus sources and trace mineral premixes, may contain cadmium (Handson 1991).

Other minerals may affect the absorption and tissue distribution of cadmium. According to Brzóska and Moniuszko-Jakoniuk (1998), the intake of an inappropriate amount of calcium causes an increased absorption of cadmium from the gastrointestinal tract and its increased accumulation in the organism.

Our results showed that there was a high inter-individual variability in the cadmium tissue concentrations. This is in agreement with Lindén et al. (2003), who found a high interindividual variability in the cadmium concentration in the kidneys between pigs, although the pigs were of the same breed, were kept on the same farm, and received the same feed. According to these authors, there are probably some yet unidentified genetic and individual factors that can have an impact on the cadmium concentrations in the kidneys of pigs other than the amount of cadmium in the feed and the environment.

The comparison of the tissue cadmium content between fattening pigs and sows has revealed a higher cadmium accumulation in the kidneys of sows. This is similar to the findings described by Ruprich et al. (2015) in cows where the mean concentration of cadmium in cow kidneys was twice as high as the mean concentration of cadmium in young bovine kidneys. This fact can be logically explained by the tendency of cadmium to cumulate in the kidneys (Jaworski 1979) and is connected with the increasing age of animals (Grawé et al. 1997). The ability of sow tissues to cumulate cadmium was demonstrated in the study by Phillips et al. (2003). The addition of cadmium to the diet ( $1 \mathrm{mg}$ cadmium per $\mathrm{kg}$ of feed) increased the concentration of cadmium in the sows' kidneys almost tenfold, while increasing the concentrations in their liver almost fivefold.

Cadmium concentrations in foods, including meat and internal organs, have been areas of interest in recent years. Meat and meat products are an important part of human diet. Although the content of heavy metals including cadmium in muscle is generally low, internal organs such as the liver and kidneys often accumulate higher metal concentrations than most other foods of animal origin. For human consumption, the European Commission (2006) has established the maximum residual limits (MRLs) for the cadmium content of $0.050 \mathrm{mg} \cdot \mathrm{kg}^{-1}$ in muscle, $0.50 \mathrm{mg} \cdot \mathrm{kg}^{-1}$ in liver, and $1 \mathrm{mg} \cdot \mathrm{kg}^{-1}$ in kidneys.

In our study, these concentrations were all within the accepted safe ranges for pigs and the MRL for human consumption was not exceeded in any sample. In recent years, much effort has been exerted to reduce the cadmium content in animal tissues. This included the legislation (EFSA 2004) and other measures, for example the introduction of raw materials with a low cadmium content in fertilizer manufacturing (Tahvonen and Kumpulainen 1994). Despite this, no significant decreasing trend in the cadmium content in tissues was observed during the time period of our trial. Based on our results, it can be concluded that there is a need for further monitoring of the cadmium content in pig tissues in the Czech Republic. 


\section{Acknowledgements}

The authors thank the Central Veterinary Administration of the State Veterinary Administration for providing the results of the examination of contaminants from the database of the Professional Information System.

This research was supported by Internal Creative Agency FVL/Illek/ITA2020, University of Veterinary and Pharmaceutical Sciences Brno, Czech Republic. Further support was provided by the RECETOX research infrastructure (the Czech Ministry of Education, Youth and Sports; LM2018121) and CETOCOEN EXCELLENCE Teaming 2 project (Horizon 2020; 857560 and the Czech Ministry of Education, Youth and Sports; 02.1.01/0.0/0.0/18_046/0015975).

\section{References}

Ammerman CB, Miller SM, Fick KR, Hansard SL 1977: Contaminating elements in mineral supplements and their potential toxicity: a Review. J Anim Sci 44: 485-508

Brzóska MM, Moniuszko-Jakoniuk J 1998: The influence of calcium content in diet on cumulation and toxicity of cadmium in the organism. Arch Tox 72: 63-73

Council Directive 96/23/EC of 29 April 1996 on measures to monitor certain substances and residues thereof in live animals and animal products and repealing Directives 85/358/EEC and 86/469/EEC and Decisions 89/187/EEC and 91/664/EEC, OJ L 125, 23.5.1996, p. 10-32 (Date of end of validity: 13/12/2019)

EFSA 2004: Opinion of the scientific panel on contaminants in the food chain on a request from the Commission related to cadmium as undesirable substance in animal feed. EFSA Journal 72: 1-24

Eriksson J, Gborn I, Jansson G, Andersson A 1996: Factors influencing cadmium-content in crops. Swed J Agric Res 26: 125-133

European Commission 2006. Commission Regulation (EC) No 1881/2006 of 19 December 2006 setting maximum levels for certain contaminants in foodstuff. Off J EU L364: 5-24

Falandsyz J 1993: Some toxic and essential trace metals in swine from Northern Poland. Sci Total Environ 136: 193-204

Grawé KP, Thierfelder T, Jorhem L, Oskarsson A 1997: Cadmium levels in kidneys from Swedish pigs in relation to environmental factors - temporal and spatial trends. Sci Total Environ 208: 111-122

Győri Z, Kovács B, Daniels P, Szabo P, Phillips C 2005: Cadmium and lead in Hungarian porcine products and tissues. J Sci Food Agric 85: 1049-1054

Hamon R, Wundke J, McLaughlin M, Naidu R 1997: Availability of zinc and cadmium to different plant species. Soil Res 35: 1267-1278

Hamon RE, McLaughlin MJ, Naidu R, Correll R 1998: Long-term changes in cadmium bioavailability in soil. Environ Sci Technol 32: 3699-3703

Handson PD 1991: Minimizing cadmium exposure in pigs. Pig Research and Development Corporation Report. Department of Agriculture and Rural Affairs, East Melbourne, Vie., 45 p.

Jalil A, Selles F, Clarke JM 1994: Effect of cadmium on growth and the uptake of cadmium and other elements by durum wheat. J Plant Nutr 17: 1839-1858

Jaworski, JF 1979: Effects of heavy metals in the Canadian environment. NRCC No. 17585. Associate committee on scientific quality for environmental criteria. National Research Council, Ottawa, Canada, 148 p.

Khan MA, Khan S, Khan A, Alam M 2017: Soil contamination with cadmium, consequences and remediation using organic amendments. Sci Total Environ 601-602: 1591-1605

Li C, Zhou K, Qin W, Tian C, Qi M, Yan X, Han W 2019: A review on heavy metals contamination in soil: effects, sources, and remediation techniques. Soil and Sediment Contamination: An International J 28: 380-394

Lindén A, Olsson I-M, Bensryd I, Lundh T, Skerfving S, Oskarsson A 2003: Monitoring of cadmium in the chain from soil via crops and feed to pig blood and kidney. Ecotox Environ Safe 55: 213-222

López-Alonso M, Miranda M, Castillo C, Hernández J, García-Vaquero M, Benedito JL 2007: Toxic and essential metals in liver, kidney and muscle of pigs at slaughter in Galicia, north-west Spain. Food Addit Contam 24: 943-954

McLaughlin MJ, Tiler KG, Naidu R, Stevens DP 1996: Review: the behaviour and environmental impact of contaminants in fertilizers. Aus J Soil Res 34: 1-54

Nikolic D, Djinovic-Stojanovic J, Jankovic S, Stanisic N, Radovic C, Pezo L, Lausevic M 2017: Mineral composition and toxic element levels of muscle, liver and kidney of intensive (Swedish Landrace) and extensive (Mangulica) pigs from Serbia. Food Addit Contam: Part A 34: 962-971

Oborn I, Jansson G, Johnsson L 1995: A field study on the influence of soil pH on trace element levels in spring wheat (Triticum aestivum), potatoes (Solanum tuberosum) and carrots (Daucus carota). Water Air Soil Pollut 85: $835-840$

Phillips C, Győri Z, Kovács B 2003: The effect of adding cadmium and lead alone or in combination to the diet of pigs on their growth, carcass composition and reproduction. J Sci Food Agric 83: 1357-1365

Ruprich J, Drápal J, Řehůřková I, St'astný K, Kalivodová M 2015: Cattle tissues as a source of cadmium for consumers. Acta Vet Brno 84: 289-295

Satarug S, Baker JR, Urbenjapol S, Haswell-Elkins M, Reilly PEB, Williams DJ, Moore MR 2003: A global perspective on cadmium pollution and toxicity in non-occupationally exposed population. Toxicol Lett 137: 65-83 
Stohs S 1995: Oxidative mechanisms in the toxicity of metal ions. Free Radical Biol Med 18: 321-336

Tahvonen R, Kumpulainen J 1994: Lead and cadmium contents in pork, beef and chicken, and in pig and cow liver in Finland during 1991. Food Addit Contam 11: 415-426

Tu YJ, Han XY, Xu ZR, Wang YZ, Li WF 2007: Effect of cadmium in feed on organs and meat colour of growing pigs. Vet Res Commun 31: 621-630

Waalkes MP 2000: Cadmium carcinogenesis in review. J Inorg Biochem 79: 241-244 